DOI: 10.17707/AgricultForest.63.2.04

\author{
Houshang NOSRATI, Saidmansor MIRTAJEDDINI, \\ Mahmoudreza JAHANSHAHI, Ahmad Razban HAGHIGHI ${ }^{1}$
}

\title{
PHYTOSOCIOLOGIAL STUDY OF RABOR REGION, KERMAN, IRAN
}

\begin{abstract}
SUMMARY
The patterns of plant associations are correlated with environmental factors. Therefore, information on association between vegetation and ecological factors is important for understanding the stability and dynamics of plant communities. This work studied phytosociology of Rober (Kerman, Iran) by analyzing the associations between vegetation and environmental factors based on Braun Blanquet method using 25 randomly sampled relevés (plots or quadrats) and determining growth form based on Raunkiaer. The relevé size was determined using Minimal Area method. For vegetation data, species richness and evenness, and percentage plant surface covers were recorded within the relevés. For environmental data, different edaphic and topographic information e.g. soil moisture, $\mathrm{pH}$, electrical conductivity, slope degree and direction and altitude were measured for the relevés. Similarity among relevés was estimated using cluster analyzing based on Ward' coefficient. Canonical Corresponding Analysis (CCA) was used to study the relationship between relevés and environmental factors and to determine the most important environmental factors affecting the relevés distribution. A total of 34 species was identified. The species number per relevé varied from 23 to 29 with average of 25.2. Analyzing of species diversity among therelevés using diversity indices of Simpson, Shannon- $\mathrm{H}$, Menhinick and Margalef showed that three relevés with 23 species and only one out of 8 relevés with 24 species had smallest species diversity, while relevé with 29 species had highest diversity level. Cluster analysis showed the study site composed of three sub-associations. CCA indicated that different edaphic and topographic variables affected differently on the distribution of the relevés.
\end{abstract}

Keywords: canonical correspondence analysis, phytosociology, species richness and evenness, vegetation analysis, relevés

\section{INTRODUCTION}

The development of human civilization in the last centuries has caused different environmental problems including the habitat destruction and

\footnotetext{
${ }^{1}$ Houshang Nosrati (corresponding author: hnosrati@tabrizu.ac.ir), Mahmoudreza Jahanshahi, Department Of Plant Science, University Of Tabriz, Tabriz, East-Azerbaijan, IRAN, Saidmansor Mirtajeddini, Department Of Plant Science, Shahidbahonar University Of Kerman, Kerman, IRAN; Ahmad Razban-Haghighi, East- Azerbaijan, Agricultural and natural Resources Research And Education Center, IRAN

Notes: The authors declare that they have no conflicts of interest. Authorship Form signed online.
} 
fragmentation that consequently have dramatically changed the structure, distribution and functioning of natural ecosystems (Saunders etal., 1991; Vitouseket al., 1997). The fragmentation and destruction of the habitats has consequently caused loss of biodiversity (Sala et al., 2000;Balmfordet al., 2005;Piessens et al., 2005) and also produced main problems in the conservation biology (Fahrig, 2003;Hanski, 2005;Strantfordand Robinson, 2005).

The first changes in the environments can be observed in the vegetation. Therefore, the knowledge on vegetation pattern and its relationship with environment shave vital importance in surveying and/or monitoring of the environment and conservation biology.

Phytosociological studies mostly focused on the interaction between plant communities and the environmental factors e.g.topography, soil properties and human inferences such as grazing. Therefore, these studies are necessary for designing of the conservation programs in order for protecting the natural plant communities and biodiversity as well as understanding the vegetation changes (occurred in the past) and vegetation dynamics in the future.

Because of long phytosociological tradition, Europe has many more vegetation relevés than any other part of the world. In the last decade many electronic databases e.g. TURBOVEG (Hennekens and Schaminee, 2001)designated for vegetation plots especially phytosociological relevés were established in many European countries, which included over 4,300,000 vegetation-plots (Schaminee et al., 2009).However, the vegetation studies conducted so far in Iran are not sufficient for constructing a complete vegetation map of Iran, although many studies were recently carried out in different regions i.e. Arasbaran Forestland (Ebrahimigajoti et al., 2013) Alborze Mountanins (Naqinezhad et al. 2012; Noroozi et al. 2014; Ravanbakhsh et al. 2016).

Iran has over 1.6 million $\mathrm{Km}^{2}$ with two Mountains Chainsof Alborz and Zagrosstretching in Northwest-Northeast and northwest- southeast directions, respectively. They determine the precipitation distribution in the country so that a very large part of the country located between these Mountains Chains in the middle of the country is very dry and has two large deserts. This Central part of the country is a high plateau. The major part of the country has arid or semi-arid climate, except the coastal area of Caspian Sea in the North and Western parts of the country. The precipitation in the country is mainly affected by Mediterranean synoptic systems. Therefore, the amount of the rainfall gradually decreases from west to east of the country. There are four vegetation zones in Iran based on Zohary (1973): 1) Hyrcanian zone, which covers the coastal area of Caspian Sea, 2) Zagross zone, which extends along Zagross Chain Mountains in the West of the country, 3) Khalij-o-Ommanian zone covers the coastal areas of Persian Gulf and 4) Iran-o-Turanian zone, which is the largest vegetation zones and covers the rest of the country including the Central Plateau. The last vegetation zone includes two large deserts i.e. a vast saline desert of Dasht-Kavir in the north and a sandy very hot desert of Dasht-Lut in the south(Zohary, 1973). 
The impact of environmental variations on species richness has been less investigated using field data, especially at local scale (Statzner and Moss, 2004). The study site is located in Rabor Town, Kerman Province in Southeast part of the Central plateau between Baft Town and desert of Dasht-Lut with dry climate.

Due to a worrying situation on loss of biodiversity and environmental problems e.g. global warming and ongoing changes in land use, there is an urgent need for wide-scale scientific and applied vegetation research (Schaminee et al., 2009) especially in developing countries. This work aimed to carry out a phytosociological survey in South of Iran.

\section{MATERIALS AND METHODS}

\section{Study site}

The study site is a Protected area and situated in Kerman Province between Kerman and Jiroft cities (latitude: $29^{\circ}, 15^{\prime} \mathrm{N}$; longitude: $57^{\circ}, 7^{\prime}$ to latitude: $29^{\circ}$, $20^{\prime} \mathrm{N}$; longitude: $57^{\circ}, 6^{\prime}$ ). The area covers $2600 \mathrm{hc}$ and its altitude ranges from $2269 \mathrm{~m}$ to $3652 \mathrm{~m}$.

\section{Vegetation data}

The size of relevé in the study site was determined using the Minimal Area method. Consequently, a number of 25 quadrats were randomly sampled in the site. The vegetation data for each relevé were recorded on the basis of species number/relevé ( $\mathrm{N}=$ the presence and absent of species), individual numbers of a given species/relevé, percentage plant surface cover (\%COV), total plant surface cover (COV), surface cover of plant base (P) and surface cover of plant canopy (A).

\section{Environmental data}

For environmental data several edaphic and topographic factors including soil moisture (SM), soil acidity(pH), soil electrical conductivity (EC), slope angle degree(Slope A),slope direction (Slope D) and altitude from the sea level (Alt) were studied. Soil moisture, EC and $\mathrm{pH}$ were measured following Seshagiri (2013) and Piper (1947).

The level of species diversity was estimated for the relevés using different diversity coefficient indices i.e. Simpson, Shannon-H, Menhinick and Margalef. Consequently, species evenness was calculated for each relevé based on Shannon's diversity index. The species evenness calculated the similarity among species within a given relevé in terms of individual numbers.

The levels of similarity among the relevés were estimated using clustering analysis on the basis of the Ward's similarity index using all vegetation data: the presence and absent of species, individual numbers of a given species per relevé, percentage plant surface cover, total plant surface cover, surface cover of plant base and surface cover of plant canopy.

To determine the relationship among the environmental and vegetation data, the ordination analysis of Canonical Correspondence Analysis (CCA) was conducted in order to find out the most effective environmental factors on the distribution of relevés. 


\section{RESULTS AND DISCUSSION}

Using Minimal Cover Area method, the size of relevé was determined to be $16 \times 16 \mathrm{~m}$. A total of 34 species was identified in 25 relevés sampled in the study site with average richness value (species/relevé) of 25.2 (Table 1). The systematic identification of the plant species was carried out using Flora Iranica (Rechinger 1963 -2005) and double checked with herbarium type specimens. The smallest number of species/relevé (23 species) was found in relevés number 17, 21 and 25, while the highest value of species/relevé (29 species)was found in relevé number 1.The dominant species among all plots was Juniperus excelsa, which occurred in all 25 relevés with a total number of 117 individual plants, averaging 4.7 plant per plot. Therefore, the site was herein called Juniperetum association. The individual plant number of the species within the relevés ranged from 2 to 9 plants with overage of 4.7 .

Table 1: The alphabetic order of the species identified within 25randomly sampled relevés in Juniperetum association

\begin{tabular}{|c|c|c|c|}
\hline 1 & Acer monspessulanum L. & 18 & $\begin{array}{c}\text { Ephedra intermedia Schranket } \\
\text { C. A. Mey. }\end{array}$ \\
\hline 2 & Aegopordon berardioides Boiss. & 19 & Euphorbia hebecarpa Boiss. \\
\hline 3 & Allium scabriscapum Boiss. \& Ky. & 20 & Geranium tuberosumL. \\
\hline 4 & Alyssum inflatum Nyarady. & 21 & Hieracium hoppeanum Schultes. \\
\hline 5 & Artemisia Aucheri Boiss. & 22 & Hordeum bulbosum L. \\
\hline 6 & Astragalus cephalanthus DC. & 23 & Ixiolirion tataricum(Pall.) Herb. \\
\hline 7 & Astragalus microcephalus Willd. & 24 & Juniperus excels M. B. \\
\hline 8 & Astragalus rhodosemius Boiss. & 25 & Muscari longipesBoiss. \\
\hline 9 & Astragalus spachianus & 26 & Oryzopsis barbellata (Mez.) Bor. \\
\hline 10 & Boiss. \& Buhse. & 27 & Paronychia Bungeii Boiss. \\
\hline 11 & Bromus rubens L. & 28 & Pistacia atlanticaDesf. \\
\hline 12 & Cirsium sp. & 29 & Sonchus asper (L.) Hill. \\
\hline 13 & Colchicum Schimperi Janka. & 30 & Stipa parviflora Desf. \\
\hline 14 & Cotonea sterintegerrima Medicus. & 31 & Thalictru misopyroidesC.A.Mey. \\
\hline 15 & Cousinia calcitrapa Boiss. & 32 & Tragopogon crocifolius L. \\
\hline 16 & Daphne mucronata Royle. & 33 & Vulpia myuros (L.) C.C. Gmel. \\
\hline 17 & Ebenus stellate Boiss. & 34 & Ziziphora tenuior L. \\
\hline
\end{tabular}

Analyzing of species diversity among 25 relevés in the study site using different diversity indices showed that the relevés number 4 (with 24 species), 17, 21 and 25 (all with 23 species) had the smallest diversity level, while plot number 1 with 29 species had the highest diversity coefficient (Table 2). For example, based on Simpson diversity coefficient, relevés number 4, 17, 21 and 23 had smallest diversity level of 0.9565 while relevé number 1 had highest level of 0.9655. Similarly, based on Shannon, relevés No. 4, 17, 21 and 23 had minimal species diversity of 3.135 while relevé No. 1 had largest value of 3.367. 
These values on the basis of Menhinick diversity coefficient were 4.796 against 5.385, and based on Margalef diversity coefficient were 7.016 versus 8.315 (Table 2). The species diversity coefficient among the relevés is similar. This indicates that the distribution of the species is constant in the study area. Moreover, the values of Simpson diversity coefficient are close to 1 in all of the relevés , indicating that the species richness within the relevés is high.

The levels of species richness in 23 out of 25 relevés were larger than 0.9998 with a range varying from 0.9865 to 1.0000 , (Table 2).

Table 2: Species richness and evenness in 25 relevés in Juniperetum vegetation

\begin{tabular}{|c|c|c|c|c|c|c|}
\hline \multirow{2}{*}{$\begin{array}{c}\text { Relevé } \\
\text { No. }\end{array}$} & $\begin{array}{c}\text { No. of } \\
\text { Species } \\
\text { (Richness) }\end{array}$ & $\begin{array}{c}\text { Simpson-1- } \\
\text { D }\end{array}$ & $\begin{array}{c}\text { Shannon } \\
\text { H }\end{array}$ & Menhinick & Margalef & Evenness \\
(Shannon)
\end{tabular}


The variations of environmental factors among 25 relevés in the study site are shown in Table 3. The soil EC among relevés ranged from 146 to 357, and the SM varied from 28 to 46 . The range of variation of soil $\mathrm{pH}$ was 7.8 - 8.7. Slope A varied from 21 to 44 degree while Slope D ranged from 45 to 360 (Table $3)$.

Correlation analysis showed that species diversity coefficient werevery significantly correlated with the number of species in the relevés (Figure1; N=25, $V_{\text {alue }}<0.00001$, at $\mathrm{P}<0.05$ level, Pearson rank correlation test).
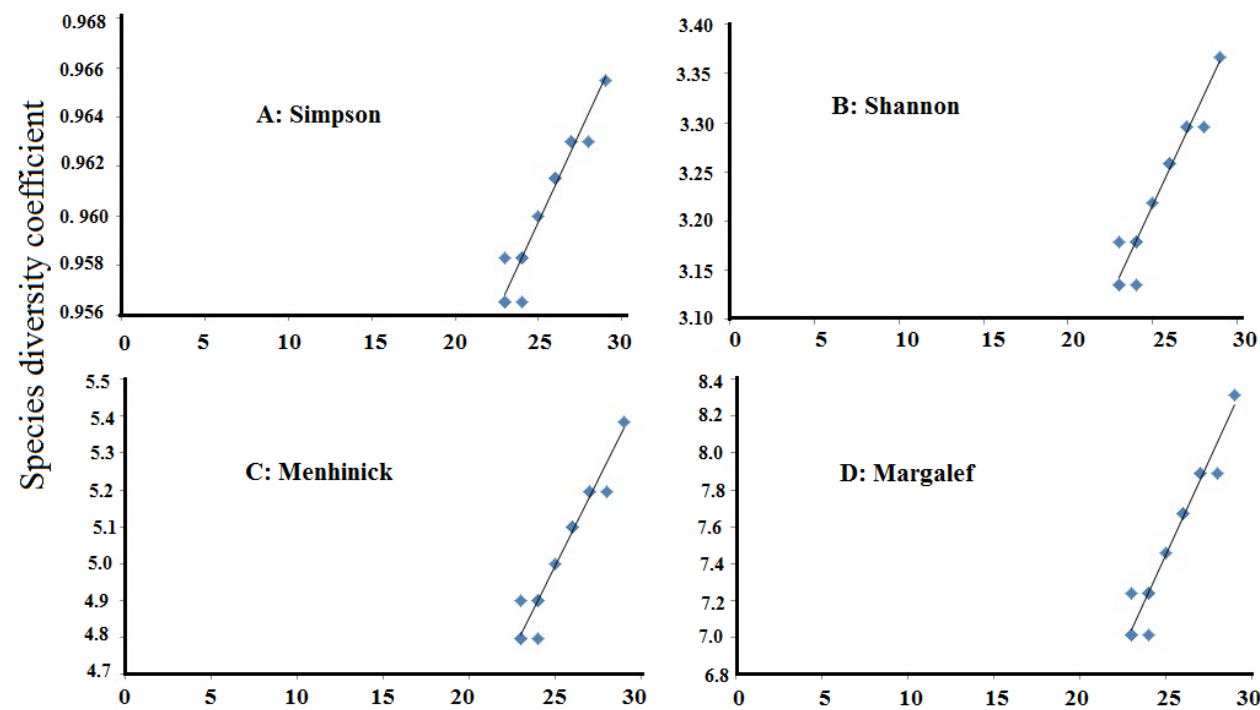

Number of species per releve

Figure 1. The positive significant correlation between species number and diversity coefficient among 25 relevés.

The clustering analysis of the relevés based on the similarity showed that the study site composed of three sub-associations (A, B and C in Figure 2). The sub-association A comprising of the relevés numbers 1, 2, 3, 4, 5, 7, 12, 13, 16, 17 was mostly affected by soil EC and $\mathrm{pH}$ (Figure 3), while the environmental factors of slop-A had strong impact on the sub-association C, which is composed of plots numbers 9, 14, 22, 23. SM had higher impact on plots 19 and 24 (Figure $3)$.

The ordination analysis of CCA between environmental and vegetation data revealed that the highest value of total vegetation variations $(48.83 \%)$ was reflected in axis 1 while small amount of the total variation (21.73\%) was shown in the axis 2 (Figure3). CCA also revealed the impact of environmental factors on percentage plant surface covers (\% COV), individual numbers of species $(\mathrm{N})$ and cover surface of plant base (P) in the study site.

Furthermore, the impact of environmental factors on the distribution of the relevés was diverse. In other words, the relevés were differently affected by the 
environmental factors. For instance, the relevés numbers 14, 15 and 22 were strongly affected by COV and \%COV, while the relevés numbers 25 and 23 were respectively influenced by $\mathrm{N}$ and $\mathrm{P}$, whereas soil $\mathrm{pH}$ had strong impact on relevés 3 and 11, while relevé 19 was affected by soil moisture (SM).

Table 3: Variation of environmental factors among 25 relevés in Juniperetum vegetation

\begin{tabular}{|c|c|c|c|c|}
\hline Variable & Minimum & Maximum & Mean & S.D. $^{1}$ \\
\hline EC & 146.0 & 357.0 & 222.7 & 64.4 \\
\hline $\mathrm{pH}$ & 7.8 & 8.70 & 8.30 & 0.25 \\
\hline Soil Moisture & 28.0 & 46.0 & 38.60 & 5.25 \\
\hline Altitude from sea level & 2269.0 & 3652.0 & 2585.3 & 285.75 \\
\hline slop A & 21.0 & 44.0 & 30.5 & 5.4 \\
\hline slop D & 45.0 & 360.0 & 183.6 & 105.5 \\
\hline
\end{tabular}

${ }^{1}$ : S.D. = Standard Deviation

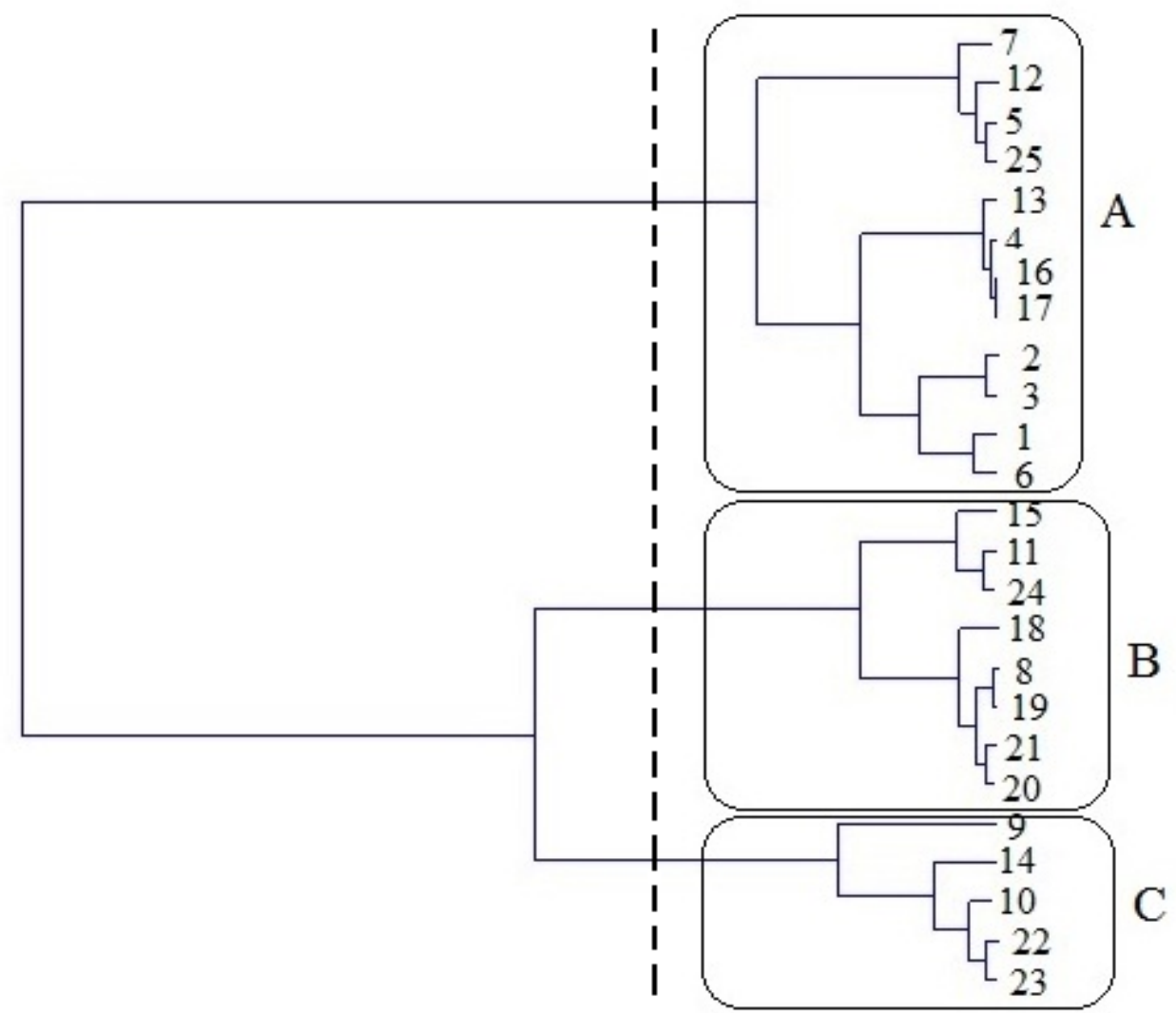

Figure 2: Clustering analysis of the relevés in the study site based on Ward's similarity showed that the vegetation of the site is composed of three sub-association of $\mathrm{A}, \mathrm{B}$ and $\mathrm{C}$ (the broken line indicates the cutoff point, determined by clustering software analysis). 


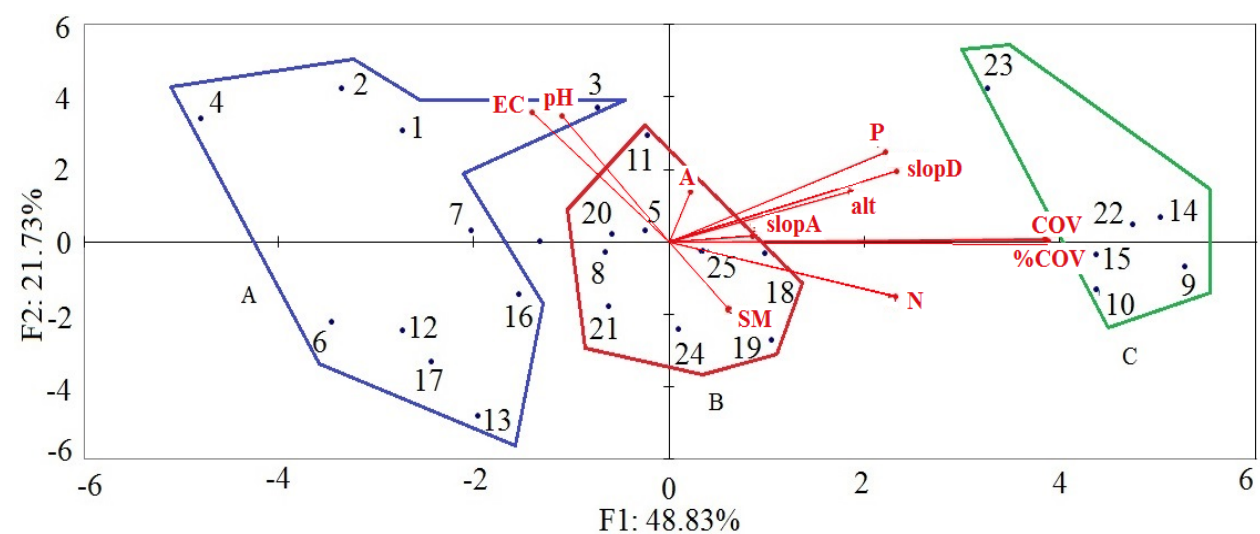

Figure3. Ordination analysis showing the relationship between environmental (vectors) and vegetation (numbered dots representingrelevés)componentsin thestudy sitebased on the CCA. The classification of the relevés into three subassociation was based on clustering analysis $(\% \mathrm{COV}=$ Percentage of plant covers surface; $\mathrm{COV}=$ total plant covers surface, $\mathrm{P}=$ covers surface of plant base, $\mathrm{A}=$ cover surface of plant canopy, $\mathrm{N}=$ species number/relevé, $\mathrm{SM}=$ soil moisture, $\mathrm{pH}=$ soil acidity, $\mathrm{EC}=$ soil electrical conductivity, Slope $\mathrm{A}=$ slope angle degree, Slope D slope direction, Alt = altitude from the sea level).

Based on the vegetation classification form of Raunkiaer, the majority (30\%) of the species growing in the study site were the rophytes followed by cryptophytes (28\%), of which $26 \%$ was geophytes.

Grouping the species growing in the study site in three different clusters indicates that there are three vegetation types, which might be corresponds with three sub-associations. However, the high similarity of indices in the species evenness among all 25 relevés sampled in the study site (close to 1) indicates that the variation among relevés is very low. This shows that the study site is a consistent plant vegetation. In the current study the results obtained from ordination and clustering analyses were corresponding with each other, both showing the three sub-associations in the study site. Similar results were reported by a phytosociological study in North of the country, in which both clustering and ordination analyses identified two corresponding vegetation types (Naqinezhad et al. 2012). While a phytosociological investigation in Arasbaran Forestland recognized six vegetation types while ordination analysis identified only three groups (Ebrahimigajoti et al. 2010).

Despite locating in semi-arid region, the vegetation types of the study site were not strongly affected by soil moisture. This fact can be also implied from the fact that in the species compositions of the relevés there were not xerophyte plants (see Table 1).The species composition of the vegetation types recognized in the present study were different from those of other vegetation types identified in other semi-arid neighboring regions in the country reported by previous studies (Akhani and Ghorbanli, 1993). 


\section{CONCLUSION}

This study showed that different ecological factors (i.e. edaphic and topographic) had differently impact on the species composition of the study site.

The current study showed that different environmental factors have diverse impact on distribution of different species compositions in any plant vegetation. Moreover, detecting the most affecting environmental factors on the species biodiversity and composition can be used in management of plant vegetations and renovating of the destruction sites of plant vegetations.

\section{REFERENCES}

Akhani H., Ghorbanli M.(1993). A contribution to the halophytic vegetation and flora of Iran, in $\mathrm{H}$. Leith and A. Al- Masoom (eds.). Towards the Rational use of High Salinity Tolerant Plants, vol. 1, p. 35-44, Kluwer Academic publishers, Netherlands.

Balmford A., Bennun L., Brink BT., Cooper D., Cote LM., Crane P. (2005). The convention on biological diversity, 2010 target. Science, 307: 212-213.

Braun BlanquetJ. (1983). Plant Sociology. Translated by G. D. Fuller and H. S. Conard. McGraw.Hill Book Company, Inc., New York, 439 p.

Ebrahimigajoti T., Nosrati H., Razban-Haghighi A., Khanbabai M. (2013). Studying biodiversity of plant associations in sutan-Chay Basin in Arasbaran, Northwest of Iran. Agriculture \& Forestry, 59(1): 85-98.

Fahrig L. (2003) Effects of habitat fragmentation on biodiversity.Annual Review of Ecology, Evolution and Systematics.34: 487-515.

Hanski I. (2005). The Shrinking World: Ecological Consequences of Habitat Loss. International Ecology Institute, Oldendorf/Luhe, Germany.

Hennekens SM., Schaminee JHJ. (2001). TURBOVEG, a comprehensive data base management system forvegetation data. Journal of Vegetation Science. 12: 589591.

Naqinezhad A., Bahari SH., Gholizadeh H.,Esmaeili R., Hamzeh’ee B., Djamali M., Moradi H. (2012). A phytosociological survey of two lowland Caspian (Hyrcanian) remnant forests, Northern Iran, for validation of some forest syntax. PhytologiaBalcanica 18(2): 173-186.

Noroozi J., Willner W., Pauli H.,Grabherr G. (2014).Phytosociology and ecology of the high-alpine to subnival scree vegetation of N and NW Iran (Alborz and Azerbaijan Mts.).Appl Veg Sci, 17(1): 142-161. DOI:10.1111/avsc.12031

Piessens K., Honnay O., Hermy M. (2005). The role of fragment area and isolation in the conservation of heathland species.Biological Conservation. 122: 61-69.

Piper CS. (1947). Soil and Plant Analysis. 1st Edn.,University of Adelaide, Australia, pp: 368.

Ravanbakhsh H., Hamzeh'ee $\quad$ B., Etemad V., Mohadjer MR.,Assadi M. (2016).Phytosociology of JuniperusexcelsaM.Bieb. forests in Alborz mountain range in the north of Iran. Plant Biosystems 150 (5)

Rechinger KH. ed., Flora Iranica: Flora des iranischenHochlandes und der umrahmendenGebirge, Graz, Austria, 1963- (in progress).

Sala OE., Chapin FS., Armesto JJ. (2000). Global biodiversity scenarios for the year 2100. Science 287: 1770-1774.

Saunders DA., Hobbs RJ.,Margules CR. (1991). Biological Consequences of Ecosystem Fragmentation: A Review.Conservation Biology, 5(1) 18-32. 
SchaminnJHJ.,Hennekens SM., Chytry M., Rodwell JS. (2009). Vegetation-plot data and databases in Europe: an overviewPreslia 81: 173-185,

Seshagiri-Rao P, Sujatha B, Lakshminarayana K, Ratnam SV. 2013. A study on phytosociology, soil conservation and socio-economic aspects in red sand dunes near Bhimili of Visakhapatnam.Archives of Applied Science Research, 5 (1):4556.

Statzner B., Moss B.(2004). Linking ecological function, biodiversity and habitat: a minireview focusing on older ecological literature. Basic Applied Ecology. 5:97-106.

Strantford JA., Robinson WD. (2005). Gulliver travels to the fragmented tropics: geographic variation in mechanisms of avian extinction. Front Ecology and Environment, 3: 85-92.

Vitousek PM., Aber JD., Howarth RW. (1997). Human alteration of the global nitrogen cycle: sources and consequences. Ecological Application. 7, (3) 737-750.

Zohary M. (1973). Geobotanical foundations of the Middle East, volume1,2. Gustav Fischer Verlag, Stuttgart,Germany. 